\title{
MAGARS AND THEIR INDIGENOUS KNOWLEDGE SYSTEMS AND PRACTICES IN TANAHU DISTRICT OF NEPAL
}

Shyamu Thapa Magar *

\section{Introduction:}

In every community, indigenous knowledge systems (IKSs) have been developed and practiced for the adaptation with the environment. People in the traditional societies are directly dependent on the natural resources in their daily lives. Both men and women are directly involved in resource utilization, management and protection using their indigenous knowledge system. Both have their own level of knowledge and practices for managing their resources. Their knowledge is also transfered from one generation to another though some indigenous knowledge has been forgotten without bringing it in practice due to various interventions. Both individuals and groups have been practicing these IKSs in their respective environments. People's participation in decision-making, group dynamism and people's role in resource mobilization, cost effectiveness and sustainability also contribute to continue and extend IKSs according to the context and situation. Research on indigenous knowledge system and practice explicitly sets out the connections between local people's understanding and practice as well as understanding by the outsiders (as the emic and etic approach) like researchers and development workers in the field (Roades1984, et. al). For the benefit of the local people, promoting valuable traditional practices and culturally appropriate and environmentally sustainable adaptations during the exploitation of the resources by the local people shows the importance of the protection of

\footnotetext{
* Shyamu Thapa Magar is a Lecturer in Anthropology at the Central Department of Sociology/Anthropology. Currently, she is pursuing her Ph. D. research work in Anthropology.
} 
the IKSs in the hill areas. In the recent years, IKS is deteriorating due to the intervention of the new technologies especially among the ethnic communities like the Magars.

This paper aims at analyzing the gender aspect of IKSs practiced by both males and females as distinct knowledge legacies in the regime of forest products and local herbs. The rationale for this analysis is that women's knowledge and men's knowledge encompasses gender specific roles as prescribed by the society and supervisory functions for the conservation of particular biodiversity domains and cultural dynamics (Hugh-J ones, 1979, and Reichel 1980, 1993).

\section{Theoretical Stance:}

E mpirical researches in N epal have shown that the IKSs are found in the sustainable management of four natural resources such as water (for irrigation), forest, soil and herbal medicines. They have shown that natural resources management by the farmers using indigenous knowledge system have been found more effective than agency- managed systems especially in the community forestry and irrigation system in Nepal.

Referring to Russel.L.Barsh, Andrew Gray (1999) asserts that local knowledge has important social and legal dimensions. Every ecosystem is conceptualized as a web of social relationships between a specific group of people such as family, clan or tribe and other species with which they share a particular place. So ecological model often appears in the stories of marriages or alliances among species through the negotiation order in which all species are bound together by kinship and solidarity, summarizing through five legal corollaries. These corollaries are: (i) every individual bears a personal responsibility for understanding and maintaining their relationship with the knowledge of ecosystem as moral, legal, and adaptations are not only expected to teach their insights to others, but also to mediate conflicts between humans and other species; (ii) knowledge confers heavy responsibility as well as the power to interfere with relationship between humans and non-humans, and must be transmitted personally to an individual apprentice who has been properly prepared to accept the burdens and to use the power with humility results together with the moral development of pupil by his/her courage, 
maturity and sincerity; (iii) the knowledge is transmitted between kins which pertains to inherited responsibilities to their own ancestral territory; (iv) the knowledge must be localized and cannot necessarily be applicable to other ecosystems; sometimes knowledge can be shared with visitors to the territory so that they can travel safely and subsist from local resources but knowledge cannot be alienated permanently from ecosystem to which it pertains; and the misuse of knowledge might bring catastrophe for the good and harmony.

IKS has been practiced in Nepal since time immemorial. Research studies on forest resources and their protection and management have made it clear that indigenous systems of forest management are widely distributed throughout $\mathrm{N}$ epal (T amang, 1990). Some argue that indigenous and traditional knowledge management systems use "effective management" based on the capacity of rural people to use in many ways their own environments (Fisher, 1991 and Gurung, 1987). They also suggest that there should not be any interventions from outside and people should be encouraged to manage natural resources as per their own interests and situations for their protection and sustenance. The Sherpas of Nepal have also been known for their IKS in the regime of forest management. For instance, Furer-Haimendorf (1964) gave one of the earlier accounts on indigenous forest management systems among the Sherpas in Nepal. He has given a good description of the 'Shinggi Nawa', a practice of communal system of the Sherpas of Solukhumbu. The 'Shinngi Nawas' were totally managed by people appointing officials for a fixed period after which they passed forest and pasture management on to others making confirmed individuals support to established rules and regulations for forest use.

Haimendorf reported that the replacement of "Shinggi Nawa" by in-effective system imposed by the Forest Department led to the degradation of the forest resources of Solukhumbu. A variation of this system in the Khumbu region is that the watchers were called forest guardians who were elected or selected among the users' households. These guardians have the duty and authority to protect forests (Haimendorf, 1964; Steven, 1993). According to Haimendorf, the Sherpas of Solukhumbu use their forest in their own ways and they have their own rules and regulations on preserving and protecting the forests. 
70 Occasional Papers, Vol 11

This study is also based on local rules and their customs which is also based on indigenous knowledge system and management of resource management.

Fisher (1989) and Gilmour (1991) also shared about forest resource management in many villages of in Sindhupalchok and Kabhrepalanchok districts where local people without outside guidelines made institutional arrangements for the protection and management of local forests. They had formed formal committees to establish and uphold rules and regulations. Forest watchers were appointed who were called ' $C$ hitadhars' in local term. The forest users collected certain amount of money from each households and paid watchers. Forest products were collected during specified period and children were not allowed to cut green grass due to becoming less experienced, avoid damaging seedlings. This kind of indigenous management of natural resources has also been found to be practiced in far western of $\mathrm{Nepal}$ (Chhetri and Pandey, 1992).

Devkota (1992), in his case study on traditional system of forest and pasture management in Thokarpa, found that traditional management systems of local natural resources were successful to prevent the local forest and pastures resources in Thokarpa from degradation and extinction. When cadastral survey took place, local management responsibilities of the natural resources were taken away from the local people by the government and the traditional rules were broken that led to the destruction and degradation of the natural resources.

Local people have their own ways of utilization and controlling mechanisms while using natural resources (Gurung, 1988) having cultural and religious practices such as restriction on women while entering into the forest for cutting grasses and fodder during menstruation. $\mathrm{N}$ ot only women, men are also restricted on changing roof with thatched grass (khar) on the day of Sarun (Chhetri, 1994 and Thapa 1996). While dealing with popular participation, it has been important to deal local culture in the working area. Some aspects of forest protection and management are human-centered, human-controlled and humanmanipulated culture through specific norms, values and beliefs. It is normal to find differences in the strategies in different societies. Religious 
fencing has been crucial in some places in far-western Nepal. People have different strategies to control resources; the most effective methods have been a process of sanctioning those users' who go against the predetermined local decisions to close access to resources ( $C$ hhetri and Pandey, 1992 and Tamang, 1990). Some strong controlling mechanism has been the threat of getting divine punishment when going against the local rules, seemed affective. Local people are using their unproductive land to generate income by using their indigenous knowledge systems and practices by planting cardamom inside community forest as well as in their private fallow land in eastern $\mathrm{N}$ epal (Thapa Magar, 2000).

Traditional indigenous knowledge systems were also practiced even after the promulgation of Private Forest Nationalization Act 1957, due to poor forest management by people for adequate protection, management and utilization by all people (Talbott and K hadka, 1994). The F orest Act 1961 was the first comprehensive forest legislation in Nepal's history. It was an attempt to institute better management of the forest. After Nepal's National Forestry Plan proposed in 1976 as the need of Community Forestry Programme for the management of the Forest (N NFP 1979), several laws were passed defining government authority over the forest and regulating use of those resources. In 1977 and 1978, Panchayat Forest (PF) and Panchayat Protected Forest (PPF) were introduced under the Community Forestry Development Programme (CFDP) with the purpose of handing back the protection and management of the forest to the community (Chhetri and Pandey, 1992) which restricted local indigenous knowledge systems and practices utilizing local natural resources.

\section{Study Locale and Methodology:}

This paper is based on the study conducted in two Village Development Committees (VDCs), namely, Sundhara and Bhagwatipur, in Tanahu District of western $\mathrm{N}$ epal. Both qualitative and quantitative data have been collected to fulfill the objective of this study. Quantitative data have been collected by administering a total of 190 questionnaires through household survey with the help of field enumerators. Qualitative data have been collected through the participant observation, key informant interviews, and focus group discussions. Quantitative data collected from 
72 Occasional Papers, Vol 11

the survey questionnaires were analyzed through Statistical Package for Social Science (SPSS) program. The data had been coded and entered into SPSS programme and analyzed by statistician. Qualitative data have been analyzed thematically by searching patterns in the data. The analyzed data have been interpreted by researcher.

In Nepal, many traditional systems of natural resource management are not indigenous system because they have been set up as a governmental interventions (Rai and Thapa, 1993). In human ecological and ethnoscience perspectives, very few action research studies have been conducted in the context of $\mathrm{Nepal}$ though several researches have been completed in the development perspectives in indigenous knowledge systems especially in people's participation in resource mobilization in forestry, irrigation and farming systems (Sillitoe, 1998).

\section{Rationale of the Study of the Indigenous K nowledge and Practice among the Magars:}

Numerous scholars and researchers have studied natural resources and common property resource management systems in $\mathrm{Nepal}$. Moreover, some scholars have generalized theories on common property resource management based on their research findings. However, not a single study has been conducted on the Magars of Tanahu District about their indigenous knowledge systems and practices with a gendered perspective.

Magars, one of the largest ethnic groups among 59 indigenous ethnic groups of $\mathrm{N}$ epal, has been found settling from western to eastern $\mathrm{N}$ epal, known as hill people of $\mathrm{Nepal}$ whose livelihood depends on natural resources such as forest and water for their living. They have an agrarian subsistence economy supported by remittance from military services such as Nepal Army, Indian Army and British Army. Magars constitute 7.14 percent among the 59 indigenous/ethnic groups in Nepal. The total population of the Magars is $16,22,421$ of which the number of males is 784828 and number of females is 837593 (CBS, 2002). Given the fact that Magars are the subsistence farmers, they interact with their environments for eking out their living. While managing, protecting and utilizing the natural resources in their respective environments, both men and women use their own level of knowledge as they have learned 
in their communities. Hence, it is necessary to study indigenous knowledge system and practices of Magars for understanding their adaptation with environment in which they live.

\section{Demographic, Cultural and E conomic Characteristics of the Magars:}

The total population of Bhagwatipur VDC, which was also known as Resing (a historical place ruled by M agars), is 7979 of which 3756 are males and 4223 females. The total population of the Sundhara VDC is 7471 with 3504 males and 3957 females (CBS 2002).

Tanahu area has been known as Barha Magarath. Ale and Rana Magars with different sub-castes have inhabited the study VDCs. Magar language is predominatly spoken in these VDCs. Nepali language has been used as lingua-franca in this area while interacting with other caste group people. Magars of Bhagwatipur VDC identified themselves as Hindus whereas the Magars of Sundhara VDC claimed to be Buddhists (a relatively recent trend).

Magars of the study VDCs are predominatly subsistence farmers. Howerver, their household economy is also supported by the overseas employment, recruitment in the $\mathrm{N}$ epalese, Indian and British armies, teaching job, petty business, wage labor, etc. Land has been always a vital for the farmers for their living. However, as elsewhere, the ownership of the land resource is traditionally controlled by the males-a function of patriarchy. A nimal husbandry has been the integral part of the agrarian economy of the study VDCs. A nimals have been raised for meat, milk products, manure for agricultural fields, and sale for coping with the household cash-crunch situation. They are also raised for sacrificing to propitiate the local deities.

\section{Indigenous Knowledge System and Practices with Gender Perspective:}

The word "indigenous" refers to the point of origin, the source of initiatives. Indigenous systems may incorporate elements and processes from outside world, provided the initiative for their incorporation is local. Traditional systems are old by definition, but indigenous knowledge systems are often quite new and constantly evolving. Thus, although traditional systems may be indigenous and vice versa, this is not 
74 Occasional Papers, Vol 11

necessarily the case (Gill, 1993). Studying indigenous system with gender perspective needs to understand the concept of gender which refers to those culturally assigned behaviors and meanings such as sex roles attributed to the distinction of all human societies make between male and females (Barfield, 1997). In this concept, understanding indigenous knowledge systems and practices with gender persppective tries to find out how males and females understand and use this system while mobilizing the resources for their living.

\section{Forest M anagement Systems in Study A rea:}

Forest always plays a vital role in Magar people's life in two VDCs of $T$ anahu District. The dependency on forest has compelled the Magars to maintain close relationship with environment while using forest products. Forest used to be dense in the past but after a haphazard utilization, forest in Bhagwatipur has almost disappeared. Later on, people started to protect forest in the name of the Sunaula Y uwa Club club after the plantation of Sal (Shoria robusta). Some years later, the process of handing over the government forest into the hand of Community Forest U ser Groups (CFUGS) had provision of restriction on entering into the forest for cutting Sal fodder but has allowed collecting floor grass and dried firewood even today. Due to young forest condition (which is not sufficient to fulfill the need of the people), they used fodder, firewood from their own private land as well as government land which is not handed over to the local people in the form of community forest.

In Sundhara VDC, people are allowed to collect floor grass openly but firewood collection has been allowed only during the thinning and pruning time (a forest management process inside community forest decided by users twice in a year). Besides all these, users also use forest products from their own private lands to fulfill their needs. Fodder and floor grass are collected from the forest by users. Looking through gender perspective, both males and females $(57 \%)$ collect firewood from forest in the study area. But on an average, nearly one third females (32.1\%) collect firewood and grass as their main task which is done by an insignificant number of males $(6.2 \%)$. When asked about the low percentage of male collecting firewood and grass from the forest, they claimed that males work outside home and village most of the time which 
compels women to work more than males. U sually collected firewood is brought home with the help of neighbors and relatives. Sometimes parma or exchange labor is used for this purpose. Sometimes, money is paid to economically poor for fectching the firewood.

Respondents were also asked about the purpose of collecting firewood. A large majority (75.8\%) reported that they collect firewood for the household purpose. Only 24.2 percent answered that they collect to cook kudo (gruel) for the livestock. Females collect branches of trees and twigs, grass and leaves as fodder and leaf litter for animal beddings whereas males collect wood for timber, big trees branches, firewood, poles for house building as well as for supports for the vegetable climbers. Because of the young forest condition, people prefer to go to their own private forests and other government forests instead of Community Forest in Bhagwatipur VDC.

\section{Community Forest User Group (CFUG) Activities:}

Forest users participate in forest management, protection and conservation as well as supervision according to their Operational Plan (OP) based on their constitution. People are more protection-oriented than utilizationoriented which is more discernible in Bhagwatipur VDC.

\section{Membership in Forest User Group (FUG):}

All villagers who use forest products from community forest are members in community forest users' group. As a member, every user has to contribute to community forest either financially or physically. In Sundhara VDC, users are more aware of community forest while using forest products. But in Bhagwatipur VDC, there has been the passive involvement of the users in forest management (because the forest there is young and unproductive).

\section{Theft of the Forest Products and Process of Controlling Mechanism:}

Scarcity forces a person to violate the existing rules and regulations to fulfill his/her needs. In rural area, those people who do not have sufficient private forest land and do not have enough time to contribute to the FUG 
76 Occasional Papers, Vol 11

and do not have enough money to buy firewood from CF, are forced to go against the rules and regulations of the community forest. However, such rule violators are often afraid of being apprehended by the CFUG community members.

\section{Awareness on Controlling Mechanism for Stealing Forest Products:}

The operational plans of community forests (CFs) have the provision that the theft/stealing of the forest products is punishable. A $n$ attempt has been made to determine the level of users' awareness on controlling mechanism. A majority of the respondents $(62.1 \%)$ reported their awareness followed by 20.5 percent reporting the lack of knowledge. But given the fact that there are no rules for the control of the extraction of herbs specified in the operational plan, the herbs are already overexploited and are on the verge of extinction.

\section{A wareness on the Responsibilities of Users in CF:}

A $n$ attempt has also been made to understand the awareness on the responsibilities of users in community forest. It has been found that a majority of respondents $(63.2 \%)$ reported that they are aware of their responsibility as users in the $\mathrm{CF}$.

\section{Females' Role in Crafting the Local Rules and Regulations:}

Given the fact that the Magar community is also heavily influenced by patriarchal values, women are always seen as subordinated to men. Women's voices are not heard-a function of lack of education and exposure to other places except the district headquarters. As a result, males have traditionally monopolized the the decision-making processes both in the household and community. W omen are selected as the members of CFU G committee simply to fulfill the basic criteria of Forest A ct and Policy. This is axiomatic of the fact that they have virtually no role in crafting the local rules and regulations.

\section{Women's Role on Resource Mobilization:}

Women's participation in resource mobilization has a vital importance for family. M ostly, social roles are divided along the lines of sex. U sually, 
males work outside the house while dealing with the monetary issues and village social problems. Females are always focused in their own household chores and do not give interest to participate in group activities (Given the fact that males are taking part in these).

\section{User Group Fund and Its Uses:}

Finance plays an important role on development activities in a community. The CF fund is collected through community development programmes, fines, playing bhailo in Tihar, monthly contribution from the user households and sale of forest products. In this context, an attempt was made during the period of the survey to understand the knowledge of the users on their fund of CF. The survey has revealed that an overwhelming majority of the respondents $(82.6 \%)$ reported their knowledge on it. It has also been ascertained that disputes related to the financial matters are solved within the group. The collected fund has been used for a variety of purposes such as for social activities (33.3\%), purchasing utensils $(32.3 \%)$, issuing loans $(23.3 \%)$, etc. It has also been used for building rest houses for travelers and maintaining water taps in the community.

\section{Women's Involvement in Forest Management and Protection:}

Participation in forest management by both males and females is essenial as members of the families. But it has not been compulsory for women to participate when there is a male member in a family. In the absence of males, females usually take part as a member of the family. A propos of the division of work, they are assigned to clean forest floor and collect leaf litters, small twigs and branches of trees for fuelwood. U sually males' work is seen as a difficult and hard such as climbing, felling tree branches, and measuring firewood for distribution. The survey has also revealed that a large majority of respondents $(63.7 \%)$ have been in favor of women's active role in CFUG activities.

\section{Dispute Settlement within a Users' Group:}

Disputes are the functions of dissatisfactions among people when their interests are un-met. The survey has revealed a multitude of reasons of 
78 Occasional Papers, Vol 11

dispute occurrence. Thes include: unequal division of workload among user households, elitist attitude of leadership, financial issues (vis- a-vis transparency), inequitable resource distribution among users, less representation of deprived groups and authoritarianism. It has also been revealed that most of the disputes arise due to males' irresponsibilities. Generally, males' role in settling the disputes has been accepted but in some cases, the role of active females (as commuity leaders) is also accepted.

Indigenous Knowledge about Local Herbal Medicine and its M anagement Systems:

Herbal medicine plays important role in rural areas in the absence of allopathic and ayurvedic medicine for the treatment of stomach-ache, headache and other illnesses for both males and females in the study areas. L ocal people have different kinds of indigenous knowledge systems to utilize those local herbs available in their agricultural fields as well as in the forests. There are various types of local herbs which have been used by local people for cure of different illnesses and but there is no any kind of mechanism to protect them from haphazard utilization. M ost of the herbs have been collected by faith-healers who are using them to cure local people but do not have any idea of protecting these valuable resources. Interestingly, the survey has also shown that a majority of the respondents $(66.1 \%)$ have been found to be using these herbs for treatment. Generally, people use tree barks, roots, and leaves of the herbs for their treatment of illnesses such as gastritis, bone fracture, muscle sprain, tonsillitis, irregular menstruation of women, dog bite, snake bite, headache, fever, sinusitis, stomach-ache, abortion, uterus prolapsis and warding off the evil spirits from a person's body for good health. M ostly herbs are collected by males, al beit women also collect a very few of them. But females are familiar with local procedures of using them (see Table 1 below).

These herbs are collected from the government forest, community forest and the own private lands of local farmers. It has been ascertained that there is no institutional culture of protecting the valuable herbs from being extinct. Local rituals and beliefs lead people to continue their cultural practices but it has been learned that these have now disappeared. 
Despite the fact that there is the haphazard collection of these herbs, locals have left the space in the forests and private lands for the benefit of their future generation by encouraging for the promotion of this indigenous knowledge systems in the study area.

\section{Recapitulation:}

Given the fact that Magars are the subsistence farmers, they interact with their environments for eking out their living. While managing, protecting and utilizing the natural resources in their respective environments, both men and women use their own level of knowledge as they have learned from their communities. Magars have reciprocal relationship with environment and hence, they are using their indigenous knowledge systems on utilizing, managing and protecting forest products from their immediate environment.

\section{R eferences}

Bista, D. B. 1972 Peoples of Nepal. Kathmandu: Ratna Pustak Bhandar.

Chhetri, Ram 1994 Indigenous and Community Forestry Management System: Reviewing the Strengths and Weaknesses. Kathmandu

Chhetri, R.B. and Pandey, T.R, 1992 User Group Forestry in the FarWesternRegion of Nepal: Case Studies from Baitadi and Achham. ICIM OD, Kathmandu.

Devkota, P.L. 1992: Traditional systems of Forest and Pasture. Kathmandu.

Furer-Haimendorf, Christoph von 1975 Himalayas Traders: Life in Highland Nepal. London: John M urry.

Furer -Haimendorf, Christoph von 1989 Exploratory Travels in the Highland Nepal.Sterling Publisher's Private Limited. New Delhi .

Gray, Andrew 1999. Cultural and Spiritual Values of Biodiversity. A Contemporary Contribution to the Global Bio-diversity Assessment. Intermediate Technology Publication. UNEP.

Gilmour, D.A.1989 Forest Resources and Indigenous Management in Nepal. Working Paper No.17. Honolulu: Environment and Policy Institute, EastW est Center. 
80 Occasional Papers, Vol 11

Gilmour, D.A and Fisher, R.J 1991Villagers, Forests and Foresters. The Philosophy, Process and Practice of Community Forestry in Nepal. Kathmandu.

Gurung, Om p. 1987Interrelationships among Pasture, Animal Husbandry and Agriculture: Case Study of Tara. HMG, USAID. viz, Winrock Project, Kathmandu.

CBS 2001 Population Census: National Report Central Bureau of Statistics, $\mathrm{N}$ epal

Reichel, D.Elizabeth 1999.G ender-Based Knowledge Systems in the Eco-politices of the Yukuna and Tanimuka of Northest Amazon, Colombia in a Contemporary Contribution to the Global Bio-diversity Assessment. Intermediate Technology Publication. UNEP.

Rai, Navin and Thapa M .B 1993:Indigenous Pasture Management System in High Altitude Nepal: A Review: Winrock Project, Nepal.

Talbott, Kirk (WRI) and Khadka, 1994: Handing it Over. An Analysis of the Legal and Policy Framework of Community F orestry in Nepal. Kathmandu.

Tamang D evika, 1990: Indigenous F orest M anagement System in Nepal: Review H.M.G. M inistry of A griculture (W inrock).

Tamang, P.et.al 2001Tamang Healing in the Himalaya: A Study on the Tamang Healing Knowledge and the Development Interventions In and Around Langtang National Park of Central Nepal. M ilijuli Nepal.Kathmandu.

Thapa M agar, S.2000.Cardamom Plantation inside Community Forest: Income Generating Activities: A Case Study of Sankhuwasabha District. M.Phil Dissertation Submitted to University of Bergen, Norway.

-.------1996. Forest Management in Legal Aspect: A Case Study of Manebhanjyang

Village Development Committee in Okhaldhunga District. Master Thesis Submitted to Central Department of Sociology/Anthropology, Tribhuvan University. 
Table 1: Local Names of the Herbs, Their Uses and Collection Practices

\begin{tabular}{|c|c|c|c|}
\hline $\begin{array}{l}\text { Name of } \\
\text { local herbs }\end{array}$ & $\begin{array}{l}\text { Uses as medicines } \\
\text { for treatment }\end{array}$ & $\begin{array}{c}\text { Used by } \\
\text { males/females }\end{array}$ & $\begin{array}{c}\text { Collected by } \\
\text { males/females }\end{array}$ \\
\hline Gurja gano & Used for treating gastritis & Both sexes & $\begin{array}{l}\text { Both but } \\
\text { collected more } \\
\text { by males }\end{array}$ \\
\hline $\begin{array}{l}\text { Amriso and its } \\
\text { root }\end{array}$ & $\begin{array}{l}\text { Broomsticks preparation } \\
\text { and to ward off evil spirits, } \\
\text { treatment of poison } \\
\text { swallowed and gano (gas } \\
\text { formation) }\end{array}$ & Both sexes & Both \\
\hline Bongre & Bone fracture & Male & Males \\
\hline Thuksusa root & $\begin{array}{l}\text { For warding off Begar } \\
\text { (evil eyes) which is } \\
\text { stronger than red chilli. }\end{array}$ & Both & Both \\
\hline Hadechook & Fracture or muscle sprain & Both & Males \\
\hline Sikari lahara & $\begin{array}{l}\text { For warding off Begar } \\
\text { (belief on sending small } \\
\text { reptile in stomach from } \\
\text { food by a jealous person) }\end{array}$ & Both & Males \\
\hline Akle Bir & Is used for liver infection. & Both & Males \\
\hline Aankh & $\begin{array}{l}\text { Used for muscle sprain/ } \\
\text { bone fracture }\end{array}$ & Both & Males \\
\hline $\begin{array}{l}\text { A twin banana } \\
\text { tree }\end{array}$ & For uterus prolapse & Women & Faith healers \\
\hline $\begin{array}{l}\text { Dhayero flower, } \\
\text { pakhanved, } \\
\text { hade kafal bark, } \\
\text { thulo buhari ko } \\
\text { jara, amala, } \\
\text { tulasi ko pat, } \\
\text { nim leaf, }\end{array}$ & $\begin{array}{l}\text { For menstruation } \\
\text { irregularity }\end{array}$ & Females & Faith healers \\
\hline
\end{tabular}


82 Occasional Papers, Vol 11

\begin{tabular}{|l|l|l|l|}
\hline \multicolumn{1}{|c|}{$\begin{array}{c}\text { Name of } \\
\text { local herbs }\end{array}$} & \multicolumn{1}{|c|}{$\begin{array}{c}\text { Uses as medicines } \\
\text { for treatment }\end{array}$} & $\begin{array}{c}\text { Used by } \\
\text { males/females }\end{array}$ & $\begin{array}{c}\text { Collected by } \\
\text { males/females }\end{array}$ \\
\hline $\begin{array}{l}\text { Kacho simrik } \\
\text { (tree) }\end{array}$ & $\begin{array}{l}\text { For warding off evil spirits, } \\
\text { and doing abortion and } \\
\text { bone fracture }\end{array}$ & Both & Both \\
\hline $\begin{array}{l}\text { Bankainas root, } \\
\text { snails, turmeric, } \\
\text { sikarilahara, } \\
\text { minia, }\end{array}$ & Used for bone fracture & Both & Both \\
\hline Bhuichap & Used for muscle sprain & Both & Both \\
\hline Bojo & Used for tonsillitis/ thyroid & Both & Females \\
\hline $\begin{array}{l}\text { Bikhamaha } \\
\text { spirits and curing dog } \\
\text { bites/snake bites }\end{array}$ & Both & Both \\
\hline $\begin{array}{l}\text { Bark of rijal, } \\
\text { Darshing, } \\
\text { Fokshing }\end{array}$ & Used for stomach pain & Both & Males \\
\hline $\begin{array}{l}\text { Panch pate } \\
\text { siule }\end{array}$ & Used for stomach pain & Both & Both \\
\hline $\begin{array}{l}\text { Rupila leaf, } \\
\text { tapani grass }\end{array}$ & Used for fever & Both & Both \\
\hline $\begin{array}{l}\text { Raw turmeric, } \\
\text { garlic, dubo }\end{array}$ & $\begin{array}{l}\text { Used for irregular } \\
\text { menstruation }\end{array}$ & Female & Females \\
\hline $\begin{array}{l}\text { Piru jhar, } \\
\text { aklebir, } \\
\text { Barhamase ko } \\
\text { ful, bark of } \\
\text { mahadan, } \\
\text { dakebarani, } \\
\text { shahadan bark, } \\
\text { bankasturi } \\
\text { bark, Kamar } \\
\text { katuwal } \\
\text { parasites in sal } \\
\text { tree and } \\
\text { chilaune tree) }\end{array}$ & $\begin{array}{l}\text { Used for irregular } \\
\text { menstruation }\end{array}$ & Female & Females \\
\hline
\end{tabular}


SHYAMU THAPA MAGAR: Magars and their Indigenous Knowledge... 83

\begin{tabular}{|l|l|l|l|}
\hline \multicolumn{1}{|c|}{$\begin{array}{c}\text { Name of } \\
\text { local herbs }\end{array}$} & \multicolumn{1}{|c|}{$\begin{array}{c}\text { Uses as medicines } \\
\text { for treatment }\end{array}$} & $\begin{array}{c}\text { Used by } \\
\text { males/females }\end{array}$ & $\begin{array}{c}\text { Collected by } \\
\text { males/females }\end{array}$ \\
\hline $\begin{array}{l}\text { Sankata ko } \\
\text { choop, } \\
\text { rangsing, } \\
\text { burjagana }\end{array}$ & Used for gastritis & Both & Males \\
\hline $\begin{array}{l}\text { Godhtapre, } \\
\text { Badalpate }\end{array}$ & Used for pneumonia & Both & Males \\
\hline Ardhakapale & Used for half headache & Both & Both \\
\hline Rudila leaf & Used for fever & Both & Both \\
\hline Pirpero & For sinusitis & Both & Both \\
\hline Kali nigro & $\begin{array}{l}\text { Used for easing the } \\
\text { urination }\end{array}$ & Both & Both \\
\hline Sankata flower & $\begin{array}{l}\text { Used for labor pain before } \\
\text { delivery }\end{array}$ & Both & Females \\
\hline Ajambari jhar & Used for fire burns & Both & Both \\
\hline
\end{tabular}

Fieldwork, 2008. 